\title{
Influence of Biopriming for enhancing Plant Growth and Seed Yield Attributes in Sorghum Varieties (Sorghum bicolor L. Moench)
}

\author{
Prakash $^{1 *}$, S. M. Prashant ${ }^{2}$, N. M Shakuntala ${ }^{1}$, \\ Vijay Kumar Kurnalliker ${ }^{1}$ and G. Girish ${ }^{2}$ \\ ${ }^{1}$ Department of Seed Science and Technology, College of Agriculture, Raichur, India \\ ${ }^{2}$ Agricultural Research Station, Hagari University of Agricultural Sciences, \\ Raichur-584 104, India \\ *Corresponding author
}

\section{A B S T R A C T}

Keywords

Biopriming,

Pseudomonas

fluorescence, yield

Article Info

Accepted:

12 March 2021

Available Online:

10 April 2021
Sorghum is an important tropical cereal food, feed and fodder crop. It is important grain and forage crop of semiarid regions due to its high adaptability and suitability to rainfed low input agriculture. The present experiment consist of three varieties viz., SPV-2217, GS-23 and M 35-1 and nine treatments viz., $\mathrm{T}_{\mathrm{o}}$ - Hydro priming, $\mathrm{T}_{1}-$ Azospirillum brasilense @20\%, $\mathrm{T}_{2}$ - Pseudomonas fluorescence @20\%, $\mathrm{T}_{3}$-Phosphobacteria @ $20 \%, \mathrm{~T}_{4}$ - Trichoderma harzianum @1\%, $\mathrm{T}_{5}$ - Beejamrutha @ 50\%, $\mathrm{T}_{6}-$ Vermiwash@2\%, T Seed bio primed with Pseudomonas fluorescence @ $20 \%$ in variety GS-23 $\left(\mathrm{T}_{2} \mathrm{~V}_{2}\right)$ recorded significantly highest plant height $(257 \mathrm{~cm})$ at harvest, panicle length $(23.15 \mathrm{~cm})$, panicle weight $(37.30 \mathrm{~g})$, test weight $(34.30 \mathrm{~g})$, seed yield per ha $(2540.53 \mathrm{~kg} / \mathrm{ha})$ and fodder yield per ha $(9243.56 \mathrm{~kg} / \mathrm{ha})$ compared to other treatments.

\section{Introduction}

Sorghum [Sorghum bicolor (L.) Moench], a cultivated diploid $(2 \mathrm{n}=20)$ tropical cereal $\mathrm{C}_{4}$ grass plant is a fourth most important cereal crop grown in the world. It is a monocotyledon plant of tropical origin, belonging to the family poaceae. Sorghum is called as camel of crops due to its high tolerance to water and temperature stress and also high photosynthesis efficiency. It is considered as an important crop plant in arid and semi-arid regions (Anagholi et al., 2000).

Sorghum is grown in India in an area about 4.09 mha with production of $3.48 \mathrm{~m}$ tonnes and productivity of $845 \mathrm{~kg} / \mathrm{ha}$ (Anon., 2019). As a food grain, interest in sorghum use in the developed world is growing due to dietary diversification trends like 'gluten-free' and 
'ancient grains'(Awika., 2017), as well as its increased recognition as a health promoting grain with unique bioactive compounds that contribute to reduced inflammation and adiposity, postprandial blood glucose response and other chronic conditions. Its regional importance is as much as that of wheat and rice.

Poor crop establishment is one of the major constraints reported by the farmers cultivating sorghum. Rapid and uniform field emergence are two essential prerequisites to increase yield and quality of seeds in crops. Uniformity and increased seedling emergence of directseeded crops have a major impact on final yield and quality (Gupta et al., 2008).

Seed priming is a pre-sowing seed treatment that involves the controlled hydration of seeds, sufficient to allow pre-germinative metabolic events to take place but radical emergence does not occur (Heydecker, 1975).

Priming allows the metabolic processes necessary for germination without protrusion of radicle. Priming accelerates germination and emergence (Taylor et al., 1998).

Bio priming is a good treatment system that integrates the biological and physiological aspects of enhancing growth, disease control and increase in yield, which involves coating the seed with biological agents and incubating the seed under warm and moist conditions.

Excessive and continuous use of chemical fertilizers coupled with pesticides and fungicides have damaged the cultivation and productivity. Now a days the chemical fertilizers are replaced by environment friendly bio-fertilizers. Most of the biofertilizers manufactured in India are solid carrier based and generally suffer from shorter shelf life, poor quality, high contamination and low field performance (Hegde, 2002).
Priming with PGPR increase germination and improve seedling establishment. It the physiological process of germination, but prevents the emergence of plumule and radicle. The initiation of the physiological process helps in the establishment and proliferation of PGPR on the spermosphere (Taylor and Harman, 1990).

Pseudomonas fluorescence primed seeds shows enhancement in the germination percentage, seedling growth mainly due to the production of plant growth regulators such as gibberellins, cytokinins, and indole acetic acid and it also makes increased availability of minerals and other ions (Sridevi and Manonmani, 2016).

\section{Materials and Methods}

A field experiment was conducted to study the Influence of biopriming on growth and yield parameters in sorghum (Sorghum bicolor L. Moench) varieties during rabi 2019-20 at Agricultural Research Station, Hagari. The experiment was carried out in factorial randomized complete block design (FRCBD).

The experiment consist of three varieties viz., SPV-2217 $\left(\mathrm{V}_{1}\right)$, GS-23 $\left(\mathrm{V}_{2}\right)$ and M 35-1 $\left(\mathrm{V}_{3}\right)$ and nine treatments viz., $\mathrm{T}_{\mathrm{o}}$ - Hydro priming, $\mathrm{T}_{1}$ - Azospirillum brasilense @ $20 \%, \mathrm{~T}_{2}$ Pseudomonas fluorescence @ 20\%, $\mathrm{T}_{3}$ Phosphobacteria@20\%, $\mathrm{T}_{4}$ - Trichoderma harzianum@1\%, T5-Beejamrutha@50\%, $\mathrm{T}_{6}$-Vermiwash@2\%, $\mathrm{T}_{7}-$ Vihaan@5\%, $\mathrm{T}_{8}$ - Waste decomposer @ 20\% and interaction between varieties and treatments.

\section{Results and Discussion}

In the current investigation, growth parameter differed significantly due to different seed biopriming treatments. The sorghum seeds bioprimed with Pseudomonas fluorescence @ $20 \%\left(\mathrm{~T}_{2}\right)$ recorded significantly highest plant 
height $(253.00 \mathrm{~cm})$ at harvest and days to $50 \%$ flowering and days to maturity recorded lower number of days (65.66 and 112.00 respectively). While, hydroprimed seeds $\left(\mathrm{T}_{0}\right)$ recorded significantly lowest plant height $(232.50 \mathrm{~cm})$ at harvest and days to $50 \%$ flowering and days to maturity recorded highest number of days (72.33 and 119.16 respectively).

The growth parameter differed significantly between the varieties. Among all the varieties treated with all treatments GS-23 $\left(\mathrm{V}_{2}\right)$ recorded significantly maximum plant height $(246.81 \mathrm{~cm})$ at harvest and days to $50 \%$ flowering and days to maturity recorded lower number of days (65.55 and 112.50 respectively).

While, the variety $\mathrm{M} 35-1\left(\mathrm{~V}_{3}\right)$ recorded minimum plant height $(239.10 \mathrm{~cm})$ at harvest. Days to $50 \%$ flowering and days to maturity recorded higher number of days (71.44 and 119.16 respectively) in variety SPV $-2217\left(\mathrm{~V}_{1}\right)$.

Interaction between varieties and seed biopriming treatments differed significantly for growth parameter. Seed bioprimed with Pseudomonas fluorescence @ 20\% in variety GS-23 $\left(\mathrm{T}_{2} \mathrm{~V}_{2}\right)$ recorded significantly highest plant height at harvest $(257.00 \mathrm{~cm})$ and lower number of days to $50 \%$ flowering and days to maturity (63.00 and 107.50 respectively).

While, the lowest plant height at harvest was noticed in hydropriming treatment in variety M 35-1 $\left(\mathrm{T}_{0} \mathrm{~V}_{3}\right)(227.50 \mathrm{~cm})$. Days to $50 \%$ flowering and days to maturity recorded higher number of days (75.00 and 123.00 respectively) in hydropriming treatment in variety SPV-2217( $\left.\mathrm{T}_{0} \mathrm{~V}_{1}\right)$.

All the yield parameters differed significantly due to different seed biopriming treatments. Sorghum seeds bioprimed with Pseudomonas fluorescence @ 20\% $\quad\left(\mathrm{T}_{2}\right)$ recorded significantly highest panicle length (20.28 $\mathrm{cm})$, panicle weight $(35.36 \mathrm{~g})$, test weight $(31.89 \mathrm{~g})$, seed yield per hectare (2318.82 $\mathrm{kg} / \mathrm{ha})$ and fodder yield per hectare (8673.77 $\mathrm{kg} / \mathrm{ha}$ ). While, the lowest panicle length $(15.51 \mathrm{~cm})$, panicle weight $(19.00 \mathrm{~g})$, test weight $(29.36 \mathrm{~g})$, seed yield per hectare $(1539.08 \mathrm{~kg} / \mathrm{ha})$ and fodder yield per hectare $(5270.07 \mathrm{~kg} / \mathrm{ha})$ was recorded in control $\left(\mathrm{T}_{0}\right)$.

The yield parameters differed significantly between the varieties. The variety GS-23 $\left(\mathrm{V}_{2}\right)$ recorded significantly maximum panicle length $(19.05 \mathrm{~cm})$, panicle weight $(29.42 \mathrm{~g})$, test weight $(32.97 \mathrm{~g})$, seed yield per hectare $(2116.41 \mathrm{~kg} / \mathrm{ha})$ and fodder yield per hectare $(7523.37 \mathrm{~kg} / \mathrm{ha})$. While, the minimum panicle length $(16.00 \mathrm{~cm})$, panicle weight $(22.64 \mathrm{~g})$, test weight $(28.29 \mathrm{~g})$, seed yield per hectare $(1625.82 \mathrm{~kg} / \mathrm{ha})$ and fodder yield per hectare $(6676.54 \mathrm{~kg} / \mathrm{ha})$ was recorded in variety M 35$1\left(\mathrm{~V}_{3}\right)$.

Interaction between different varieties and seed biopriming treatments differed significantly for yield parameters.

Seeds bioprimed with Pseudomonas fluorescence @ 20\% in variety GS-23 $\left(\mathrm{T}_{2} \mathrm{~V}_{2}\right)$ recorded the significantly highest panicle length $(23.15 \mathrm{~cm})$, panicle weight $(37.30 \mathrm{~g})$, test weight $(34.30 \mathrm{~g})$, seed yield per hectare $(2540.53 \mathrm{~kg} / \mathrm{ha})$ and fodder yield per hectare $(9243.56 \mathrm{~kg} / \mathrm{ha})$. While, the lowest panicle length $(14.35 \mathrm{~cm})$, panicle weight $(15.70 \mathrm{~g})$, test weight $(26.80 \mathrm{~g})$, seed yield per hectare $(1357.33 \mathrm{~kg} / \mathrm{ha})$ and fodder yield per hectare $(5122.22 \mathrm{~kg} / \mathrm{ha})$ was recorded in hydropriming treatment in variety $\mathrm{M} 35-1\left(\mathrm{~T}_{0} \mathrm{~V}_{3}\right)$.

Plants produced from primed seeds often exhibit a faster growth than unprimed ones. The beneficial impact of priming on plant growth may be due to improved nutrient use efficiency allowing a higher relative growth rate in Maize (Muhammad et al., 2015). 
Table.1 Influence of seed biopriming on plant height at harvest, Days to $50 \%$ flowering, Days to maturity and panicle length in sorghum varieties

\begin{tabular}{|c|c|c|c|c|c|c|c|c|c|c|c|c|c|c|c|c|}
\hline \multirow{2}{*}{$\begin{array}{l}\text { Treat } \\
\text { ments }\end{array}$} & \multicolumn{4}{|c|}{ Plant height at harvest $(\mathrm{cm})$} & \multicolumn{4}{|c|}{ Days to $50 \%$ flowering } & \multicolumn{4}{|c|}{ Days to maturity } & \multicolumn{4}{|c|}{ Panicle length $(\mathrm{cm})$} \\
\hline & $\begin{array}{l}\text { SPV- } \\
2217\end{array}$ & GS-23 & $\begin{array}{c}\text { M } \\
\text { 35-1 }\end{array}$ & Mean & $\begin{array}{l}\text { SPV- } \\
2217\end{array}$ & $\begin{array}{c}\text { GS- } \\
23\end{array}$ & $\begin{array}{c}\text { M } \\
\text { 35-1 }\end{array}$ & Mean & $\begin{array}{l}\text { SPV- } \\
2217\end{array}$ & GS-23 & $\begin{array}{c}\text { M } \\
35-1\end{array}$ & Mean & $\begin{array}{l}\text { SPV- } \\
2217\end{array}$ & $\begin{array}{c}\text { GS- } \\
23\end{array}$ & $\underset{35-1}{\text { M }}$ & Mean \\
\hline $\mathbf{T}_{\mathbf{0}}$ & 231.00 & 239.00 & 227.50 & 232.50 & 75.00 & 69.00 & 73.00 & 72.33 & 123.00 & 115.50 & 119.00 & 119.16 & 15.90 & 16.30 & 14.35 & 15.51 \\
\hline $\mathbf{T}_{1}$ & 247.00 & 250.50 & 243.00 & 246.83 & 70.00 & 64.00 & 67.00 & 67.00 & 117.00 & 111.00 & 114.00 & 114.00 & 18.50 & 19.90 & 16.70 & 18.36 \\
\hline $\mathbf{T}_{2}$ & 255.00 & 257.00 & 247.00 & 253.00 & 68.00 & 63.00 & 66.00 & 65.66 & 116.00 & 107.50 & 112.50 & 112.00 & 20.10 & 23.15 & 17.60 & 20.28 \\
\hline $\mathbf{T}_{3}$ & 245.50 & 249.00 & 241.00 & 245.16 & 71.00 & 64.50 & 68.00 & 67.83 & 118.00 & 112.00 & 116.00 & 115.33 & 18.05 & 19.60 & 16.30 & 17.98 \\
\hline $\mathbf{T}_{4}$ & 251.00 & 251.50 & 244.50 & 249.00 & 69.00 & 63.50 & 66.50 & 66.33 & 116.50 & 110.00 & 113.00 & 113.16 & 18.75 & 20.25 & 16.90 & 18.63 \\
\hline $\mathbf{T}_{5}$ & 241.50 & 244.50 & 239.00 & 241.66 & 72.00 & 66.00 & 70.00 & 69.33 & 120.00 & 114.00 & 117.50 & 117.16 & 17.80 & 18.65 & 15.65 & 17.36 \\
\hline$T_{6}$ & 244.50 & 245.00 & 240.40 & 243.30 & 71.00 & 65.00 & 69.00 & 68.33 & 119.00 & 113.00 & 117.00 & 116.33 & 17.85 & 19.40 & 16.05 & 17.76 \\
\hline $\mathbf{T}_{7}$ & 236.50 & 243.00 & 236.00 & 238.50 & 73.00 & 67.00 & 71.00 & 70.33 & 121.00 & 114.50 & 118.00 & 117.83 & 17.20 & 17.50 & 15.35 & 16.68 \\
\hline $\mathbf{T}_{8}$ & 234.50 & 241.80 & 233.50 & 236.60 & 74.00 & 68.00 & 72.00 & 71.33 & 122.00 & 115.00 & 118.50 & 118.50 & 17.05 & 16.70 & 15.10 & 16.28 \\
\hline Mean & 242.94 & 246.81 & 239.10 & & 71.44 & 65.55 & 69.16 & & 119.16 & 112.50 & 116.16 & & 17.91 & 19.05 & 16.00 & \\
\hline & SEM \pm & $\begin{array}{c}\text { CD } \\
(5 \%)\end{array}$ & & & SEM \pm & $\begin{array}{c}\text { CD } \\
(5 \%)\end{array}$ & & & SEM \pm & $\begin{array}{c}\text { CD } \\
(5 \%)\end{array}$ & & & SEM \pm & $\begin{array}{c}\text { CD } \\
(5 \%)\end{array}$ & & \\
\hline V & 0.332 & 0.970 & & & 0.071 & 0.206 & & & 0.086 & 0.250 & & & 0.193 & 0.136 & & \\
\hline $\mathbf{T}$ & 0.575 & 1.680 & & & 0.122 & 0.357 & & & 0.149 & 0.434 & & & 0.334 & 0.236 & & \\
\hline$V \times T$ & 0.995 & 2.910 & & & 0.212 & 0.619 & & & 0.258 & 0.752 & & & 0.579 & 0.409 & & \\
\hline
\end{tabular}


Table.2 Influence of seed biopriming on panicle weight, test weight, seed yield and fodder yield in sorghum varieties

\begin{tabular}{|c|c|c|c|c|c|c|c|c|c|c|c|c|c|c|c|c|}
\hline \multirow{2}{*}{$\begin{array}{l}\text { Treat } \\
\text { ments }\end{array}$} & \multicolumn{4}{|c|}{ Panicle weight (g) } & \multicolumn{4}{|c|}{ Test weight (g) } & \multicolumn{4}{|c|}{ Seed yield (kg/ha) } & \multicolumn{4}{|c|}{ Fodder yield (kg/ha) } \\
\hline & $\begin{array}{l}\text { SPV- } \\
2217\end{array}$ & $\begin{array}{c}\text { GS- } \\
23\end{array}$ & $\begin{array}{c}\text { M } \\
\text { 35-1 }\end{array}$ & Mean & $\begin{array}{l}\text { SPV- } \\
2217\end{array}$ & $\begin{array}{c}\text { GS- } \\
23\end{array}$ & $\underset{35-1}{M}$ & Mean & $\begin{array}{c}\text { SPV- } \\
2217\end{array}$ & GS-23 & M 35-1 & Mean & $\begin{array}{l}\text { SPV- } \\
2217\end{array}$ & GS-23 & M 35-1 & Mean \\
\hline $\mathbf{T}_{\mathbf{0}}$ & 17.80 & 23.50 & 15.70 & 19.00 & 29.60 & 31.70 & 26.80 & 29.36 & 1553.54 & 1706.40 & 1357.33 & 1539.08 & 5243.56 & 5444.45 & 5122.22 & 5270.07 \\
\hline$T_{1}$ & 27.90 & 30.80 & 24.00 & 27.56 & 31.20 & 33.40 & 28.97 & 31.19 & 1988.74 & 2341.07 & 1683.73 & 2004.51 & 7788.89 & 8010.23 & 7266.67 & 7688.59 \\
\hline $\mathbf{T}_{2}$ & 36.90 & 37.30 & 31.90 & 35.36 & 32.00 & 34.30 & 29.37 & 31.89 & 2360.47 & 2540.53 & 2055.47 & 2318.82 & 8677.78 & 9243.56 & 8100.00 & 8673.77 \\
\hline $\mathbf{T}_{3}$ & 25.80 & 29.50 & 22.70 & 26.00 & 31.00 & 33.20 & 28.60 & 30.93 & 1961.53 & 2186.93 & 1656.53 & 1934.99 & 7788.89 & 7771.34 & 7266.67 & 7608.96 \\
\hline $\mathbf{T}_{4}$ & 34.00 & 34.10 & 27.10 & 31.73 & 31.50 & 33.80 & 29.10 & 31.46 & 2188.20 & 2468.00 & 1883.20 & 2179.80 & 8233.34 & 8405.95 & 7711.11 & 8116.79 \\
\hline $\mathbf{T}_{5}$ & 24.40 & 28.10 & 21.20 & 24.56 & 30.30 & 32.70 & 28.10 & 30.36 & 1834.60 & 1969.33 & 1529.60 & 1777.84 & 6900.00 & 7132.45 & 6377.78 & 6803.40 \\
\hline$T_{6}$ & 25.60 & 28.40 & 22.30 & 25.43 & 30.80 & 32.90 & 28.50 & 30.73 & 1907.14 & 2096.27 & 1602.13 & 1868.51 & 7344.45 & 7576.89 & 6822.22 & 7247.85 \\
\hline $\mathbf{T}_{7}$ & 22.90 & 26.60 & 20.10 & 23.20 & 30.09 & 32.50 & 27.80 & 30.13 & 1771.14 & 1942.13 & 1466.13 & 1726.46 & 6900.00 & 7138.45 & 5933.33 & 6657.25 \\
\hline $\mathbf{T}_{8}$ & 21.50 & 26.50 & 18.80 & 22.26 & 29.80 & 32.30 & 27.40 & 29.83 & 1662.34 & 1797.07 & 1398.54 & 1619.31 & 6011.11 & 6987.06 & 5488.89 & 6162.35 \\
\hline Mean & 26.31 & 29.42 & 22.64 & & 30.70 & 32.97 & 28.29 & & 1914.18 & 2116.41 & 1625.82 & & 7209.78 & 7523.37 & 6676.54 & \\
\hline & SEM \pm & $\begin{array}{c}\text { CD } \\
(5 \%)\end{array}$ & & & SEM \pm & $\begin{array}{c}\text { CD } \\
(1 \%)\end{array}$ & & & SEM \pm & $\begin{array}{c}\text { CD } \\
(5 \%)\end{array}$ & & & SEM \pm & $\begin{array}{c}\text { CD } \\
(5 \%)\end{array}$ & & \\
\hline V & 0.222 & 0.646 & & & 0.029 & 0.081 & & & 8.662 & 25.182 & & & 39.086 & 113.622 & & \\
\hline $\mathbf{T}$ & 0.385 & 1.119 & & & 0.050 & 0.141 & & & 15.004 & 43.617 & & & 67.699 & 196.799 & & \\
\hline$V \times T$ & 0.667 & 1.938 & & & 0.086 & 0.244 & & & 25.988 & 75.548 & & & 117.258 & 340.867 & & \\
\hline
\end{tabular}


A higher growth of seedlings produced from primed seeds may also be analyzed in relation to a direct impact of pre-treatment on cell cycle regulation and cell elongation processes in spinach (Chen and Arora, 2013). The growth parameters of chickpea were significantly affected by seed priming (Gupta and Singh, 2012).

The promotion of growth in terms of increase in plant height has been thought to be by increasing plasticity of the cell wall followed by hydrolysis of starch to sugars which lowers the water potential of cell, resulting in the entry of water into the cell causing elongation. These osmotic driven responses under the influence of gibberellins might have been attributed to increase in photosynthetic activity, accelerated translocation and efficiency of utilizing the photosynthetic products, thus resulting in increased cell elongation and rapid cell division in the growing parts in prosomillet (Turgut et al., 2006).

The increased rate of emergence could be correlated with early flowering and early maturity observed in the present study. Similar observations in advancement of flowering were also stated by Raj et al., (2004) in pearl millet.

Harris et al., (1999) conducted on farm trail in eastern India reported that primed seeds flowered earlier and matured earlier than control. Arif (2005) indicated that plants of primed seeds reached earlier at flowering and maturity as compared to plants of nonprimed seeds in soybean.

The increase in the panicle length in $P$. fluorescence treatment may be due to the synthesis of better carbohydrates transformation which resulted in better growth and length of panicle which ultimately results in increasing the yield. Similar results are also reported by Raj et al., (2004) in pearl millet. The priming with $P$. fluorescence was evident in improving the seed yield and yield attributing factors in pearl millet (Raj et al., 2004). The enhancement in the seedling growth noticed in this study could be attributed to suppressions of deleterious microorganisms and pathogens; production of plant growth regulators such as gibberellins, cytokinins and indole acetic acid, which increased the availability of minerals and other ions and more water uptake in rice (Ramamoorthy et al., 2000).

Yield increase may also result from a higher plant density observed as a consequence of priming induced increase in germination percentage in maize (Murungu et al., 2004).

Seed priming treatment resulted in increased crop growth rate in treated seeds which encouraged deposition of more photoassimilates in key plant parts, greatly affecting the final yield in rice (Srivastava and Bose., 2012).

The highest plant height $(\mathrm{cm})$ at harvest, seed weight (g), seed yield per hectare (kg/ha), fodder yield per hectare $(\mathrm{kg} / \mathrm{ha})$ was recorded in GS-23 $\left(\mathrm{V}_{2}\right)$ compared to other varieties. This variance may be due to the varieties genetic variations and genetic composition. The findings of Altai (2014), Bahar et al., (2015), Al-Baldawi and Hamza (2017) and Shihab and Hamza (2020) in sorghum also support these results.

Among the different priming treatment sorghum seeds primed with Pseudomonas fluorescence @ 20 per cent in variety GS-23 for $12 \mathrm{~h}$ showed better growth and yield parameter viz. plant height $(\mathrm{cm})$, days to $50 \%$ flowering, days to maturity, panicle length $(\mathrm{cm})$, panicle weight $(\mathrm{g})$, seed yield $(\mathrm{kg} / \mathrm{ha})$, fodder yield $(\mathrm{kg} / \mathrm{ha})$, test weight $(\mathrm{g})$ compared to other treatments. 


\section{References}

Al-Baldawi, H. K. M. and Hamza, H. J., 2017, Seed priming effect on field emergence and grain yield in sorghum. J. Cent. Eur. Agric., 18(2): 404-423.

Altai, A. L., 2014, Hormonal regulation of tillering in sorghum (Sorghum bicolor (L.) Moench) and its influence on grain yield and its components. $M P h$. Thesis, Department of Field Crops, College of Agriculture, University of Baghdad.

Anagholi, A., Kashiri, A. and Mokhtarpoor, H., 2000, The study of comparison between inside forage sorghum cultivars and speed feed hybrids. $J$. Agric. Nat. Resour., 7(4): 73-83.

Anonymous, 2019, India sorghum production and utilization. New Delhi. Available on http:// www.indiastat.com/agriculture/2/foodg rains/17180/jowargreatmillet.

Arif, M., 2005, Effect of seeds priming on emergence, yield and storability of soyabean. Ph.D. Thesis, NWFP Univ. Peshawar. 190-195.

Awika, J. M., 2017, Sorghum: Its unique nutritional and health-promoting attributes. In Gluten-free ancient grains. Wood head publishing., 21-54.

Bahar, A. H., Adam, K. I. and Ali, S. A. M., 2015, Effect of variety and sowing date on performance of rain-fed sorghum [Sorghum bicolor (L.) Moench]. J. Agric. Eng., 1 (1): 22-7.

Chen, K. and Arora, R., 2013, Priming memory invokes seed stress-tolerance, Environ. Exp. Bot., 94: 33-45.

Gupta, A., Dadlani, M., Arun Kumar, M. B., Roy, M., Naseem, M., Choudhary, V. K. and Maiti, R. K., 2008, Seed priming: the aftermath. Int. J. Agric. Environ. Biotechnol., 1: 199-209.

Gupta, V. and Singh, M., 2012, Effect of seed priming and fungicide treatment on chickpea (Cicer arietinum) sown at different sowing depths in kandi belt of low altitude sub-tropical zone of Jammu. Appl. Biol. Res., 14: 187-92.

Harris, D. A., Joshi, P. A., Khan, P., Gothkar and Sodhi, P. S., 1999, On-farm seed priming in semiarid agriculture: Development and evaluation in maize, rice and chickpea in India using participatory Methods. Exp. Agric., 35: 15-29.

Hegde, S. V., 2002, Liquid biofertilizers in Indian Agriculture. Biofert. News Lett., 12: $17-22$.

Heydecker, W., Higgins, J. and Turner, Y. J. 1975, Invigoration of seeds. Seed Sci. Technol., 3: 881-888.

Muhammad, I., Kolla, M., Volker, R. and Günter, N., 2015, Impact of nutrient seed priming on germination, seedling development, nutritional status and grain yield of maize. J. Plant Nutr., 38: 1803-1821.

Murungu, F. S., Chiduza, C., Nyamugafa, P., Clarck, L. J., Whalley, W. R. and Finch-Savage, W. E., 2004, Effect of on-farm seed priming on consecutive daily sowing occasions on the emergence and growth of maize in semi-arid Zimbabwe. Field Crop Res., 89: 49-57.

Raj, S. N., Shetty, N. P. and Shetty, H. S., 2004, Seed bio-priming with Pseudomonas fluorescence isolates enhances growth of pearl millet plants and induces resistance against downy mildew. Int. J. Pest Manag., 50(1): 4148.

Ramamoorthy, K., Natarajan, N. and Lakshmanan, A., 2000, Seed biofortification with Azospirillum spp. for improvement of seedling vigour and productivity in rice (Oryza sativa L). J. Seed Sci. Technol., 28(3): 809815.

Shihab, M. O. and Hamza, J. H., 2020, Seed 
priming of sorghum cultivars by gibberellic and salicylic acids to improve seedling growth under irrigation with saline water. J. Plant Nutr., 1-17.

Sridevi, R. and Manonmani, V., 2016, Influence of seed priming on physiological performance of foxtail, little and proso millets. Int. J. Agric. Sci. Res., 6(4): 179-186.

Srivastava, A. K. and Bose, B., 2012, Effect of nitrate seed priming on phenology, growth rate and yield attributes in rice (Oryza sativa L.). J. Agric. Veter. Sci., 25: $174-81$.
Taylor, A. G. and G. E. Harman. 1990, Concepts and technologies of selected seed treatments. Ann. Rev. Phytopathol., 28: 321-339.

Taylor, A. G., Allen, P. S., Bennett, M. A., Bradford, K. J., Burrisand, J. S. and Misra, M. K., 1998, Seed enhancements. Seed Sci. Res., 8: 245256.

Turgut, I., Duman, A., Wietgrefe, G. W. and Acikgoz, E., 2006, Effect of seeding rate and nitrogen fertilization on proso millet under dryland and irrigated conditions, J. Plant Nutr., 29: 21192129.

\section{How to cite this article:}

Prakash, S. M. Prashant, N. M Shakuntala, Vijay Kumar Kurnalliker and Girish, G. 2021. Influence of Biopriming for enhancing Plant Growth and Seed Yield Attributes in Sorghum Varieties (Sorghum bicolor L. Moench). Int.J.Curr.Microbiol.App.Sci. 10(04): 360-367. doi: https://doi.org/10.20546/ijcmas.2021.1004.039 